\title{
PENGARUH PROFITABILITAS, UKURAN PERUSAHAAN, KEPEMILIKAN INSTITUSIONAL, DAN KOMITE AUDIT TERHADAP KETEPATAN WAKTU PELAPORAN KEUANGAN
}

\author{
Erma Setiawati \\ Email: Erma.setyowati@ums.ac.id \\ Program Studi Akuntansi Universitas Muhammadiyah Surakarta \\ Jl. A. Yani, Pabelan, Kartasura, Sukoharjo \\ Eskasari Putri \\ Email: Eskasariputri@ums.ac.id \\ Program Studi Akuntansi Universitas Muhammadiyah Surakarta \\ Jl. A. Yani, Pabelan, Kartasura, Sukoharjo \\ Nanda Devista \\ Email: nandadevista130998@gmail.com \\ Program Studi Akuntansi Universitas Muhammadiyah Surakarta \\ Jl. A. Yani, Pabelan, Kartasura, Sukoharjo
}

\begin{abstract}
Abstrak
Penelitian ini bertujuan untuk mengetahui pengaruh profitabilas, ukuran perusahaan, kepemilikan institusional, dan komite audit terhadap ketepatan waktu pelaporan keuangan pada perusahaan manufaktur yang terdaftar di Bursa Efek Indonesia periode 2017-2019. Metode pengambilan sampel yang digunakan adalah metode purposive sampling, sehingga diperoleh 84 perusahaan manufaktur selama 3 tahun. Data yang digunakan dalam penelitian ini adalah data sekunder. Teknik analisis data yang digunakan adalah metode regresi logistik. Hasil dari penelitian ini menunjukkan bahwa profitabilitas, ukuran perusahaan, kepemilikan institusional, dan komite audit tidak berpengaruh terhadap ketepatan waktu pelaporan keuangan.
\end{abstract}

Kata kunci: profitabilitas, ukuran perusahaan, kepemilikan institusional, komite audit, ketepatan waktu pelaporan keuangan

\section{Abstract}

This study aims to determine the effect profitability, firm size, institutional ownership and audit committee to the timeliness of financial reporting on manufacturing companies listed on the Indonesia Stock Exchange period 2017-2019. Sampling method used in this research is purposive sampling, so that obtained 84 manufacturing companies for period 3 years. Data used in the study is a secondary data. Analysis data technique used is logistic regression method. The result shows that profitability, firm size, institutional ownership and audit committee not significant to the timeliness of financial reporting.

Keywords: profitability, firm size, institutional ownership, audit committee, timeliness of financial reporting 


\section{PENDAHULUAN}

Perkembagan pasar modal di Indonesia saat ini telah meningkat dengan sangat pesat dan tentunya di masa mendatang bisnis investasi akan menjadi sedemikian kompleks, dengan tingkat persaingan yang sangat ketat, terutama dalam upaya penyediaan dan perolehan informasi dalam setiap pembuatan keputusan. Salah satu sumber informasi penting dalam bisnis investasi di pasar modal adalah laporan keuangan yang disediakan setiap perusahaan Go Publik.

Pelaporan keuangan merupakan sarana bagi perusahaan untuk menyampaikan berbagai informasi dan pengukuran secara ekonomi mengenai sumber daya yang dimiliki serta kinerjanya kepada berbagai pihak yang memiliki kepentingan atas informasi tersebut. Pelaporan keuangan diharapkan memberi informasi mengenai kinerja keuangan perusahaan selama suatu periode dan bagaimana manajemen dari sebuah perusahaan menggunakan tanggung jawab pengurusnya kepada pemilik.

Pelaporan keuangan yang tepat waktu merupakan hal yang penting bagi investor karena akan mengurangi ketidakpastian dalam mengambil keputusan ekonomi dan penyebaran informasi keuangan yang tidak merata diantara para stakeholder sehingga dapat merugikan berbagai pihak tidak terkecuali perusahaan tesebut. Laporan keuangan yang disajikan terlambat akan menyebabkan informasi tersebut kehilangan relevansinya dalam mempengaruhi keputusan ekonomi pemakai, dimana informasi tersebut berfungsi sebagai peramalan (predictive) dan penegasan (confirmatory). Pelaporan keuangan yang disampaikan digunakan oleh pihak-pihak yang mempunyai kepentingan terutama para investor agar dapat memaksimalkan nilai investasinya. Investor mempertimbangkan keputusan untuk berinvestasi ke salah satu perusahaan dengan membandingkan laporan keuangan yang disajikan oleh masing-masing perusahaan. Investor sebagai pemegang saham atau pemilik perusahaan dari pihak luar memerlukan laporan keuangan untuk mengetahui tingkat kembalian (rate of return) atas investasi dan membantu untuk memutuskan tindakan mereka baik untuk membeli, menahan, atau menjual saham-saham perusahaan.

Kewajiban penyampaian laporan keuangan perusahaan publik diatur dalam Keputusan Direksi PT Bursa Efek Jakarta Nomor: Kep-306/BEJ/07-2004 Tentang Peraturan Nomor I-E Tentang Kewajiban Penyampaian Informasi Laporan Tahunan harus disampaikan dalam bentuk laporan keuangan auditan, selambat-lambatnya pada akhir bulan ke-3 setelah tanggal Laporan Keuangan Tahunan. 
Berdasarkan Kerangka Dasar Penyusunan dan Penyajian Laporan Keuangan Standar Akuntansi Keuangan, laporan keuangan harus memenuhi empat karakteristik kualitatif yang merupakan ciri khas yang membuat informasi laporan keuangan berguna bagi para pemakainya. Keempat karakteristik tersebut yaitu dapat dipahami, relevan, andal, dan dapat dibandingkan. Ketepatan waktu dalam penyampaian laporan keuangan dapat mempengaruhi manfaat yang bagi para pengguna laporan keuangan. Semakin tepat waktu pelaporan keuangan disampaikan maka informasi yang terkandung didalamnya semakin bermanfaat dan para pengguna laporan keuangan dapat mengambil keputusan yang lebih baik, baik dalam segi kualitas maupun waktu. Dengan demikian perusahaan secara tidak langsung akan memperoleh manfaat yang lebih baik sebagai dampak pengambilan keputusan tesebut (Nurmiati, 2016).

\section{METODE PENELITIAN}

Penelitian ini bersifat kuantitatif. Data yang digunakan adalah data sekunder yang diambil dari data laporan keuangan perusahaan yang terdaftar di BEI (Bursa Efek Indonesia) tahun buku yang berakhir pada tanggal 31 Desember 2017 sampai Desember 2019.Data tersebut diperoleh dari website www.idx.co.id. Populasi dan sampel dalam penelitian ini adalah Perusahaan Manufaktur yang terdaftar di BEI selama periode 2017-2019 Peneliti menggunakan metode purposive sampling untuk mengambil sampel penelitian. Pengambilan sampel dilakukan dengan mengambil sampel dari populasi berdasarkan kriteria tertentu.

Dalam penelitian ini dilakukan uji statistik deskriptif, uji overall fit model, koefisien determinasi (Nagelkerke $\mathrm{R}$ square), uji goodness of fit, dan uji hipotesis dengan menggunakan metode analisis Regresi Logistik.

\section{Definisi Operasional dan Pengukuran Variabel}

Berdasarkan perumusan masalah yang telah dikaji dan ditinjau pustaka, Oporasionalisasi variabel akan diuraikan dalam pengukuran variabel yang menggambarkan hubungan atau pengaruh variabel independent dan variabel dependen. Berikut variabel-variabel dan pengukurannya dalam penelitian ini:

\section{Variabel Independen}

Variabel independen terdiri dari Profitabilitas, Ukuran Perusahaan, Kepemilikan Institusional, dan Komite Audit terhadap variabel dependen, yaitu Ketepatan Waktu Pelaporan Keuangan. Definisi operasional variabel dalam penelitian ini adalah sebagai berikut: 


\section{Profitabilitas}

Profitabilitas merupakan salah satu indikator keberhasilan perusahaan untuk dapat menghasilkan laba. Sehingga semakin tinggi profitabilitas maka semakin tinggi kemampuan perusahaan untuk menghasilkan laba bagi perusahaannya. Profitabilitas diukur melalui Return of Asset (ROA) yaitu dengan perbandingan laba bersih setelah pajak dengan rata-rata total asset. Rumus untuk menghitung ROA adalah sebagai berikut:

$$
R O A=\frac{\text { Laba Bersih Setelah pajak }}{\text { Total Aset }}
$$

\section{Ukuran Perusahaan}

Ukuran (size) perusahaan dapat diartikan sebagai suatu skala dimana suatu perusahaan dapat diklasifikasikan menjadi perusahaan besar atau perusahaan kecil dengan berbagai cara. Antara lain dinyatakan dalam total asset, total penjualan, nilai pasar saham, dan lain-lain. Jadi ukuran perusahaan merupakan ukuran atau besarnya asset yang dimiliki oleh perusahaan. Semakin besar nilai item-item tersebut maka semakin besar pula ukuran perusahaan itu. Dalam penelitian ini menggunakan total asset, jika total aktiva semakin besar maka semakin besar pula ukuran perusahaan tersebut. Rumus untuk menghitung ukuran perusahan adalah seagai berikut:

\section{Ukuran Perusahaan $=\operatorname{Ln}($ Total Aset $)$}

\section{Kepemilikan institusional}

Kepemilikan institusional adalah kepemilikan saham suatu perusahaan oleh institusi keuangan seperti perusahaan asuransi, bank, dana pensiun, dan inverstment banking. Kepemilikan saham oleh pihak luar atau pihak institusi mempunyai kekuatan untuk menuntut dan mewajibkan pihak manajemen agar menyampaikan informasi keuangan dengan segera. Karena laporan keuangan yang diserahkan terlambat akan berpengaruh terhadap keputusan ekonomi yang akan diambil oleh para pemakai informasi tesebut. Rumus untuk menghitung kepemilikan institusional adalah sebagai berikut:

$$
K I=\frac{\text { Jumlah Saham Institusi }}{\text { Jumlah Saham Beredar }}
$$

\section{Komite Audit ( $\left.\mathbf{X}_{4}\right)$}

Komite audit adalah komite yang dibentuk oleh dewan komisaris dan bertanggungjawab kepada dewan komisaris dalam membantu melaksanakan fungsi dewan komisaris, yang anggotanya diangkat dan dihentikan oleh dewan komisrais, komite audit bertindak secara 
inependen dalam melaksanakan tugas dan fungsi dewan komisari (Putri et al., 2015) dalam (Azhari dan Nuryanto, 2019)

Semakin banyak anggota komite audit yang memiliki keahlian dalam bidang keuangan maka semakin banyak pula sumber informasi dan pengetahuan yang dimiliki. Sehingga diharapkan dapat mengarahkan komite audit untuk melaksanakan tugasnya secara mandiri dan lebih objektif. Variabel ini menggunakan Dummy, pengukuran dilakukan dengan memberi nilai 1 untuk jumlah komite audit 3 atau lebih dari 3 dan memberi nilai 0 untuk komite audit yang kurang dari 3.

\section{Variabel Dependen}

Variabel dependen atau variabel terkait yang digunakan dalam penelitian ini adalah Ketepatan Waktu Pelaporan Keuangan oleh suatu perusahaan. Variabel ini menggunakan dummy. Pengukuran dilakukan dengan memberikan nilai 1 untuk perusahaan yang melakukan ketepatan waktu pelaporan keuangan dan 0 untuk perusahaan yang tidak tepat waktu menyampaikan pelaporan keuangan. Perusahaan dapat dikatakan tepat waktu dalam pelaporan keuangan apabila perusahaan tersebut telah mampu menyampaikan laporan keuangan sampai batas waktu yang telah ditentukan yaitu pada 31 Maret ditahun berikutnya. Sedangkan untuk perusahaan yang tidak tepat waktu dalam pelaporan keuangan apabila pelaporan keuangan telah melebili batas waktu yang telah ditentukan yaitu melebihi 31 Maret tahun berikutnya.

\section{Metode Analisis Data}

Metode analisis yang digunakan dalam penelitian ini adalah analisis regresi logistik. Dimana persamaan regresinya adalah sebagai berikut:

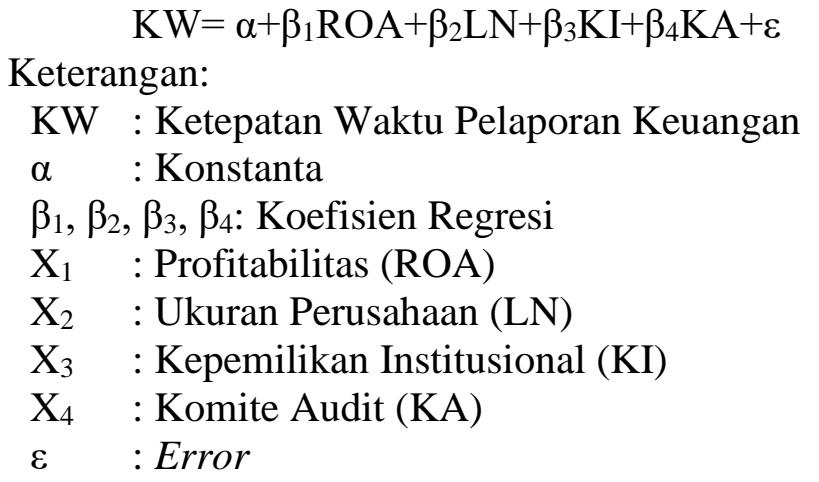




\section{HASIL PENELITIAN DAN PEMBAHASAN}

\section{HASIL}

\section{Kriteria pengambilan sampel}

Tabel 1. Kriteria Pengambilan Sampel

\begin{tabular}{|l|l|l|}
\hline No & Kriteria & Jumlah \\
\hline $\begin{array}{c}\text { Perusahaan manufaktur yang terdaftar di BEI selama } \\
\text { periode 2017-2019. }\end{array}$ & 193 \\
\hline 1. & $\begin{array}{c}\text { Perusahaan manufaktur yang tidak terdaftar secara } \\
\text { berturut-turut di BEI selama periode 2017- } \\
\text { 2019. }\end{array}$ & $(37)$ \\
\hline 2. & $\begin{array}{c}\text { Perusahaan manufaktur yang tidak menerbitkan } \\
\text { laporan keuangan tahunan yang } \\
\text { dipublikasikan di BEI secara berturut-turut } \\
\text { selama periode 2017-2019. }\end{array}$ & $(11)$ \\
\hline 3. & $\begin{array}{c}\text { Perusahaan manufaktur yang tidak memakai mata } \\
\text { uang Rupiah dalam laporan keuangan } \\
\text { tahunannya. }\end{array}$ & $(26)$ \\
\hline 4. & $\begin{array}{c}\text { Perusahaan manufaktur yang tidak mempunyai } \\
\text { kelengkapan data pelaporan keuangan } \\
\text { periode 2017-2019yang terkait variabel } \\
\text { dalam penelitian. }\end{array}$ & $(0)$ \\
\hline 5. & $\begin{array}{c}\text { Perusahaan manufaktur yang tidak mengalami laba } \\
\text { secara berturut-turut selama periode 2017- } \\
\text { 2019. }\end{array}$ & $(35)$ \\
\hline Jumlah sampel yang sesuai kriteria & 84 \\
\hline Jumlah sampel selama periode 2017-2019 (84x3) & 252 \\
\hline
\end{tabular}

Sumber: Hasil Pengolahan Data, 2020

\section{Analisis Regresi Logistik}

\section{Menilai Kelayakan Model Regresi}

Tabel 2. Hasil Uji Hosmer and Lemeshow

\begin{tabular}{|c|c|c|c|}
\hline Step & Chi-square & $\mathrm{df}$ & Sig. \\
\hline 1 & 9.486 & 8 & 0.303 \\
\hline
\end{tabular}

Berdasarkan hasil uji Hosmer and Lemeshow di atas, menunjukkan profitabilitas signifikan sebesar 0,303 yang nilainya lebih besar dari 0,05 . Hal ini berarti model regresi layak dipergunakan untuk analisis selanjutnya, karena tidak adanya perbedaan yang nyata antara klasifikasi yang diprediksi dengan klasifikasi yang diamati. Dapat dikatakan pula bahwa model mampu memprediksi nilai observasinya. 


\section{Menilai Keseluruhan Model (Overall Model Fit)}

Tabel 3. Block $0=$ Beginning Block

Iteration History ${ }^{\mathrm{a}, \mathrm{b}, \mathrm{c}}$

\begin{tabular}{llcr}
\hline Iteration & \multicolumn{2}{c}{$\begin{array}{c}\text {-2 Log } \\
\text { likelihood }\end{array}$} & $\begin{array}{c}\text { Coefficients } \\
\text { Constant }\end{array}$ \\
\hline \multirow{4}{*}{ Step 0 } & 1 & 172.576 & 1.603 \\
& 2 & 163.257 & 2.093 \\
& 3 & 162.962 & 2.201 \\
& 4 & 162.961 & 2.206 \\
\hline
\end{tabular}

Sumber : Hasil Pengolahan data dengan SPSS, 2020

Tabel 4. Block $1=$ Method $=$ Enter

\begin{tabular}{|c|c|c|c|c|c|c|c|}
\hline \multirow[t]{2}{*}{ Iteratio } & & \multirow{2}{*}{$\begin{array}{l}-2 \text { Log } \\
\text { likelihood }\end{array}$} & \multicolumn{5}{|c|}{ Coefficients } \\
\hline & & & Constant & PROFITABILITAS & $\begin{array}{c}\text { UKURAN } \\
\text { PERUSAHAAN }\end{array}$ & $\begin{array}{l}\text { KEPEMILIKAN } \\
\text { INSTITUSIONAL }\end{array}$ & $\begin{array}{l}\text { KOMITE } \\
\text { AUDIT }\end{array}$ \\
\hline \multirow{20}{*}{$\begin{array}{l}\text { Step } \\
1\end{array}$} & 1 & 170.842 & 0.313 & 0.617 & 0.048 & 0.374 & -0.402 \\
\hline & 2 & 160.035 & -0.335 & 1.504 & 0.100 & 0.738 & -1.052 \\
\hline & 3 & 159.241 & -0.243 & 2.342 & 0.128 & 0.886 & -1.988 \\
\hline & 4 & 159.154 & 0.651 & 2.579 & 0.132 & 0.891 & -2.999 \\
\hline & 5 & 159.126 & 1.654 & 2.588 & 0.132 & 0.891 & -4.005 \\
\hline & 6 & 159.116 & 2.656 & 2.588 & 0.132 & 0.891 & -5.007 \\
\hline & 7 & 159.112 & 3.657 & 2.588 & 0.132 & 0.891 & -6.008 \\
\hline & 8 & 159.110 & 4.657 & 2.588 & 0.132 & 0.891 & -7.008 \\
\hline & 9 & 159.110 & 5.657 & 2.588 & 0.132 & 0.891 & -8.008 \\
\hline & 10 & 159.110 & 6.657 & 2.588 & 0.132 & 0.891 & -9.008 \\
\hline & 11 & 159.110 & 7.657 & 2.588 & 0.132 & 0.891 & -10.008 \\
\hline & 12 & 159.110 & 8.657 & 2.588 & 0.132 & 0.891 & -11.008 \\
\hline & 13 & 159.110 & 9.657 & 2.588 & 0.132 & 0.891 & -12.008 \\
\hline & 14 & 159.110 & 10.657 & 2.588 & 0.132 & 0.891 & -13.008 \\
\hline & 15 & 159.110 & 11.657 & 2.588 & 0.132 & 0.891 & -14.008 \\
\hline & 16 & 159.110 & 12.657 & 2.588 & 0.132 & 0.891 & -15.008 \\
\hline & 17 & 159.110 & 13.657 & 2.588 & 0.132 & 0.891 & -16.008 \\
\hline & 18 & 159.110 & 14.657 & 2.588 & 0.132 & 0.891 & -17.008 \\
\hline & 19 & 159.110 & 15.657 & 2.588 & 0.132 & 0.891 & -18.008 \\
\hline & 20 & 159.110 & 16.657 & 2.588 & 0.132 & 0.891 & -19.008 \\
\hline
\end{tabular}

Dari tabel diatas menunjukkan perbandingan antara nilai -2 Log Likelihood Block Number $=0$ dan -2 Log Likelihood Block Number $=1$. Nilai pada -2 Log Likelihood Block Number $=0$ sebesar 162,961 dan nilai -2 Log Likelihood Block Number $=1$ sebesar 159.110. hal tersebut menunjukkan adanya penurunan antara nilai -2 Log Likelihood Block Number $=0$ 
dan -2 Log Likelihood Block Number = 1 yang berarti bahwa model regresi yang lebih baik atau dapat dikatakan bahwa model regresi yang dihipotesiskan fit dengan data.

\section{Menganalisis Koefisien Determinasi (Nagelker R Square)}

Tabel 5. Hasil Uji Koefisien Determinasi

\begin{tabular}{cccc}
\multicolumn{4}{c}{ Model Summary } \\
\hline Step & $\begin{array}{c}-2 \text { Log } \\
\text { likelihood }\end{array}$ & $\begin{array}{c}\text { Cox \& Snell } \\
\text { R Square }\end{array}$ & $\begin{array}{c}\text { Nagelkerke R } \\
\text { Square }\end{array}$ \\
\hline 1 & $159.110^{\mathrm{a}}$ & 0.015 & 0.032 \\
\hline Sumber : Hasil pengolahan data dengan SPSS, 2020 \\
\hline
\end{tabular}

Berdasarkan hasil tabel diatas, menunjukkan bahwa nilai Nagel $R$ Square sebesar 0,032. Hal ini berarti secara bersama-sama variabel profitabilitas $\left(\mathrm{X}_{1}\right)$, ukuran perusahaan $\left(\mathrm{X}_{2}\right)$, kepemilikan institusional $\left(\mathrm{X}_{3}\right)$, dan komite audit $\left(\mathrm{X}_{4}\right)$ dapat menjelaskan variasi variabel ketepatan waktu pelaporan keuangan (Y) sebesar 3,2\% sedangkan sisanya 96,8\% dijelaskan oleh variabel lain diluar model penelitian.

\section{Uji Hipotesis}

Tabel 6.Hasil Analisis Regresi Logistik

\begin{tabular}{|c|c|c|c|c|c|c|c|}
\hline \multicolumn{8}{|c|}{ Variables in the Equation } \\
\hline & & $\mathrm{B}$ & S.E. & Wald & Df & Sig. & $\operatorname{Exp}(B)$ \\
\hline \multirow{5}{*}{$\begin{array}{l}\text { Step } \\
1^{\mathrm{a}}\end{array}$} & PROFITABILITAS & 2.588 & 2.918 & 0.787 & 1 & 0.375 & 13.309 \\
\hline & $\begin{array}{l}\text { UKURAN } \\
\text { PERUSAHAAN }\end{array}$ & 0.132 & 0.106 & 1.544 & 1 & 0.214 & 1.141 \\
\hline & $\begin{array}{l}\text { KEPEMILIKAN } \\
\text { INSTITUSIONAL }\end{array}$ & 0.891 & 1.308 & 0.464 & 1 & 0.496 & 2.437 \\
\hline & KOMITE AUDIT & -19.008 & 20077.750 & 0.000 & 1 & 0.999 & 0.000 \\
\hline & Constant & 16.657 & 20077.750 & 0.000 & 1 & 0.999 & 17141656.670 \\
\hline
\end{tabular}

Dari hasil pengujian dengan regresi logistik diatas, maka diperoleh persamaan sebagai berikut:

$$
\mathrm{KW}=16,657+2.588 \mathrm{ROA}+0.132 \mathrm{LN}+0.891 \mathrm{KI}+(-19.008 \mathrm{KA})+\varepsilon
$$

\section{PEMBAHASAN}

\section{Pengaruh Profitabilitas terhadap Ketepatan Waktu Pelaporan Keuangan}

Variabel profitabilitas yang diukur menggunakan ROA tidak berpengaruh terhadap pelaporan keuangan perusahaan manufaktur yang terdaftar di BEI periode 2017-2019. Hal ini ditunjukkan oleh hasil signifikansi 0,375>0,05, sehingga $\mathrm{H}_{1}$ dalam penelitian ini ditolak, artinya profitabilitas perusahaan tidak berpengaruh terhadap ketepatan waktu pelaporan keuangan. 
Hasil penelitian ini sejalan dengan penelitian yang dilakukan oleh Probokusumo, Utomo dan Nuraina (2017) yang menunjukkan bahwa profitabilitas tidak berpengaruh secara signifikan terhadap ketepatwatuan (timelines) penyampaian laporan keuangan. Tetapi penelitian ini tidak sejalan dengan hasil penelitian yang dilakukan oleh Azhari dan Nuryanto (2019) menunjukkan bahwa profitabilitas berpengaruh positif terhadap ketepatan waktu pelaporan keuangan.

\section{Pengaruh Ukuran Perusahaan Terhadap Ketepatan Waktu Pelaporan Keuangan}

Variabel ukuran perusahaan yang diukur menggunakan Ln Total Asset tidak berpengaruh terhadap pelaporan keuangan perusahaan manufaktur yang terdaftar di BEI periode 2017-2019. Hal ini ditunjukkan dengan hasil signifikansi 0,214 >0,05, sehingga $\mathrm{H}_{2}$ dalam penelitian ini ditolak, artinya ukuran perusahaan tidak berpengaruh terhadap ketepatan waktu pelaporan keuangan.

Hal tersebut dikarenakan besar kecilnya ukuran perusahaan tidak menjamin apakah perusahaan tersebut akan tepat waktu dalam menyampaikan pelaporan keuangannya. Perusahaan yang mempunyai ukuran besar ataupun kecil mempunyai kewajiban yang sama untuk memberikan informasi mengenai perusahaanya kepada publik secara tepat waktu. Sebuah informasi yang disampaikan secara tepat waktu akan mendapatkan kepercayaan dari publik mengenai laporan keuangan tersebut.

Hasil penelitian sejalan dengan penelitian yang dilakukan oleh Indrayenti dan Cindrawati (2016) menunjukkan bahwa ukuran perusahaan tidak berpengaruh terhadap ketepatan waktu penyampaian pelaporan keuangan. Tetapi tidak sejalan dengan penelitian yang dilakukan oleh Rahma, Lusiana, dan Indriyani (2019) yang menunjukkan bahwa ukuran perusahaan berpengaruh positif dan signifikan terhadap ketepatan waktu pelaporan keuangan.

\section{Pengaruh Kepemilikan Institusional Terhadap Ketepatan Waktu Pelaporan \\ Keuangan}

Variabel kepemilikan institusional yang diukur menggunakan Jumlah saham institusi/Jumlah saham beredar tidak berpengaruh terhadap ketepatan waktu pelaporan keuangan, hal ini ditunjukkan dengan hasil signifikansi 0,496>0,05, sehingga $\mathrm{H}_{3}$ dalam penelitian ini ditolak, artinya kepemilikan institusional tidak berpengaruh terhadap ketepatan waktu pelaporan keuangan.

Dalam hal ini dikarenakan bahwa tidak adanya hubungan yang signifikan antara tingkat kepemilikan oleh pihak luar atau institusi dengan ketepatan waktu pelaporan 
keuangan suatu perusahaan. Tidak berpengaruhnya kepemilikan institusional terhadap ketepatan waktu pelaporan keuangan diduga karena kurangnya pengawasan dari pihak institusi selaku pemegang saham dan pihak institusi lebih lebih mementingkan angka dalam laporan keuangan terutama laba (profit) dari pada waktu penyampaian laporan keuangan

Penelitian ini sejalan dengan penelitian yang dilakukan oleh azhari dan Nuryanto (2019) menunjukkan bahwa kepemilikan institusional tidak berpengaruh terhadap ketepatan waktu pelaporan keuangan. Tetapi tidak sejalan dengan penelitian yang dilakukan oleh Isani dan Ekowati (2016) yang menunjukkan bahwa kepemilikan institusional berpengaruh signifikan terhadap ketepatan waktu pelaporan keuangan.

\section{Pengaruh Komite Audit Terhadap Ketepatan Waktu Pelaporan Keuangan}

Variabel komite audit yang diukur menggunakan Dummy tidak berpengaruh terhadap ketepatan waktu pelaporan keuangan, hal ini ditunjukkan dengan hasil signifikansi 0,999 $>0,05$, sehingga $\mathrm{H}_{4}$ dalam penelitian ini ditolak, artinya komite audit tidak berpengaruh terhadap ketepatan waktu pelaporan keuangan.

Dalam hal ini dikarenakan banyak tidaknya anggota komite audit tidak berpengaruh terhadap ketepatan waktu pelaporan keuangan. Peran penting komite audit adalah mengawasi audit laporan keuangan dan memastikan apakah penyusunannya telah mengikuti prosedur dan pedoman yang berlaku, serta menilai mengenai mutu pelayanan dan kewajaran biaya yang dibuat oleh auditor eksternal. Maka artinya komite audit tidak mempengaruhi ketepatan waktu pelaporan keuangan suatu perusahaan.

Penelitian ini sejalan dengan penelitian yang dilakukan oleh Effendi (2019) menunjukkan bahwa komite audit tidak berpengaruh terhadap ketepatan waktu pelaporan keuangan. Tetapi tidak sejalan dengan penelitian Azhari dan Nuryanto (2019) yang menunjukkan bahwa komite audit berpengaruh positif terhadap ketepatan waktu pelaporan keuangan.

\section{KESIMPULAN}

Kesimpulan dari penelitian adalah variabel profitabilitas,ukuran perusahaan, kepemilikan institusional dan komite audit tidak berpengaruh terhadap ketepatan waktu pelaporan keuangan. 


\section{DAFTAR PUSTAKA}

Adebayo, P. A and W. K. Adebiyi. (2016). Effect of Firm Characteristics on The Timesliness of Corporate Financial Reporting: Evidence from Nigerian Deposit Money Bank. International Jaournal Of Economics, Commerce and Management. Vol. IV, No. 3: 369-381.

Astuti, W dan Erawati. T. (2018). Pengaruh Profitabilitas, Umur Perusahaan dan Ukuran Perusahaan Terhadap Ketepatan Waktu Penyampaian Laporan Keuangan Perusahaan. Jurnal Kajian Bisnis. Vol. 26, No. 2. 144-157.

Azhari, Fadhli dan Muhammad Nuryatno. (2019). Peran Opini Audit Sebagai Pemoderasi Pengaruh Profitabilitas, Ukuran Perusahaan, Kepemilikan Institusional, Dan Komite Audit Terhadap ketepatan Waktu Pelaporan Keuangan. JRAMB, Prodi akuntansi, Fakultas Ekonomi, UMB Yogyakarta.Volume 5 No. 1., Mei 2019, ISSN: 2460-1233.

Azhari, Fadhli dan Muhammad Nuryatno. (2020). Peran Opini Audit Sebagai Pemoderasi Pengaruh Profitabilitas, Ukuran Perusahaan, Kepemilikan Institusional Dan Komite Audit Terhadap Ketepatan Waktu Pelaporan Keuangan. Jurnal Magister Akuntansi Trisakti.Vol.7. No 1 Februari 2020:61-84, ISSN:23390859.

Carolina, Jessica dan Vargo Christian L. Tobing. (2019). Pengaruh Profitabilitas, Likuiditas, Solvabilitas Dan Ukuran Perusahaan Terhadap Ketepatan Waktu Penyampaian Laporan Keuangan Pada Perusahaan Manufaktur Di BEI. Jurnal Akuntansi Barelang. Vol.3 No.2 2019.

Danaatmaja, Andhika R dan Leny Suzan. (2018). Pengaruh Rasio Keuangan Terhadap Ketepatan Waktu Penyampaian Laporan Keuangan (Studi Empiris Pada Perusahaan Pertambangan Yang Terdaftar Di BEI Periode 2012-2016). The Influence of Financial Ratio of The Timeliness of Financial Reportin. EProceeding of Management. Vol 5, No.1 Maret 2018, ISSN: 2355-9357.

Dewayani, M. A, dkk. (2017). Analisis Faktor-Faktor Yang Mempengaruhi Ketepatan Waktu Pelaporan Keuangan (Studi Empiris Pada Perusahaan Manufaktur Yang Terdaftar Di BEI Periode 2011-2016). Jurnal Universitas Muhammadiyah Magelang. ISSN: 2407-9189.

Ghozali, Imam. (2012). Aplikasi Analisis Multivariate dengan Program IBM SPSS. Yogyakarta Universitas Diponegoro.

Harnida, Muthia. (2015). Pengaruh Mekanisme Corporate Governance Terhadap Ketepatan Waktu Penyampaian Pelaporan Keuangan (Studi Empiris Pada Perusahaan Publik Yang Terdaftar Di BEI). JSAI. Vol. 2, No.1 Juni 2015.

Kasmir. (2012). Analisis Laporan Keuangan. Jakarta: PT. Raja Grafindo Persada.

Keputusan Direksi PT Bursa Efek Indonesia Nomor: Kep-306/BEJ/07/2004. Tentang Peraturan nomor I-E Tentang Kewajiban Penyampaian Informasi.

Kusumawati, Eni. Dkk. (2018). Analisis Laporan Keuangan (Tinjauan Kasus dan Riset Empiris). 
Mahadewi, Istri Sri dan Komang Ayu Krisnadewi. (2017). Pengaruh Kepemilikan Manajerial, Institusional Dan Proporsi Dewan Komisaris Independen Pada Manajemen Laba. E-Jurnal Akuntansi Universitas Udayana. Vol. 18, No. 1 Januari 2017:443-470, ISSN: 2302-8556.

Mahendra, I. B. K.Y dan I. N. W. A. Putra. (2014). Pengaruh Komisaris Independen, Kepemilikan Institusional, Profitabilitas, Likuiditas dan Ukuran Perusahaan Terhadap Ketepatwaktuan. E-Journal Akuntansi Universitas Udayana. Vol. 3, No. 1:180-199.

Nurmiati. (2016). Faktor-Faktor Yang Mempengaruhi Ketepatan Waktu Pelaporan Keuangan. Jurnal Ekonomi dan Manajemen. Vol. 13, No 2. ISSN: 2528-1127.

Oktavia, H. D dan Suryanigrum. D. H. (2018). Pengaruh Profitabilitas, Opini Auditor dan Ukuran Perusahaan Terhadap Ketepatan Waktu Penyampaian Laporan Keuangan di BEI Periode 2012-2014. Jurnal Keuangan dan Bisnis. Maret 2018.

Ousii, A. A and N. B. Taktak. (2018). Audit Committee Effectiveness and Financial Reporting Timesliness: The Case of Tunisian Listed Companies. African Journal of Economic anda Management Studies. Vol. 9, No. 1:35-55.

Pradipta, D. M dan B. Suryono. (2017). Analisis Faktor-Faktor Yang Mempengaruhi Ketepatan Waktu Pelaporan Keuangan. Jurnal Ilmu Dan Riset Akuntansi. Vol. 6 No.3:1200-1216.

Putri, Pramudia. B. (2015). Pengaruh Karakteristik Komite Audit, Fee Audit, Ukuran KAP dan Internal Auditor Terhadap Ketepatan Waktu (Timeliness) Pelaporan Keuangan (Studi Empiris Pada Perusahaan yang Listing di BEI 2013). Jom FEKON. Vil. 2 No 2. Oktober 2015.

Rahma, Anita Ade. Dkk. (2019). Pengaruh Struktur Modal, Profitabilitas dan Size Perusahaan Terhadap Ketepatan Waktu Pelaporan Keuangan Pada Perusahaan Manufaktur. Jurnal Benefita. 4(2) Juli 2019 (210-220).

Sanjaya, K. W. S dan N. G. P. Wirawati. (2016). Analisis Faktor-Faktor Yang Mempengaruhi Ketepatan Waktu Pelaporan Keuangan Pada Perusahaan Manufaktur Yang Terdaftar Di BEI. E-Jurnal Akuntansi Universitas Udayana. Vol. 20, No. 2:1592-1620.

Sugiyono. (2013). Metode Penelitian Pendidikan Pendekatan Kuantitatif, Kualitatif, dan $R \& D$. Bandung: Alphabeta.

Suwardjono. (2012). Teori Akuntansi Perekayasa Pelaporan Keuangan. Edisi 3 Yogyakarta: BPFE Yogyakarta.

Utami, Dewi dan Yennisa. (2017). Faktor-faktor Mempengaruhi Ketepatan Waktu Pelaporan Keuangan Pada Perusahaan Sub Sektor Bank Di BEI. Jurnal Akuntansi Dewantara. Vol. 1, No. 1 April 2017.

$\underline{\text { www.idx.ac.id }}$ 